\title{
Die identifisering van 'n geskikte vraelys vir die bepaling van lewenskwaliteit by Suid-Afrikaanse vroue met servikskanker
}

\author{
Author: \\ George du Toit ${ }^{1}$ \\ Affiliation: \\ ${ }^{1}$ Department of Obstetrics \\ and Gynaecology, \\ Stellenbosch University, \\ South Africa \\ Correspondence to: \\ George du Toit \\ Email: \\ dutoitg@worldonline.co.za \\ Postal address: \\ Van der Stelstraat 50, \\ Stellenbosch 7600 \\ South Africa \\ Dates: \\ Received: 26 Aug. 2014 \\ Accepted: 08 Dec. 2014 \\ Published: 30 Apr. 2015 \\ How to cite this article: \\ Du Toit, G., 2015, 'Die \\ identifisering van 'n geskikte \\ vraelys vir die bepaling \\ van lewenskwaliteit by \\ Suid-Afrikaanse vroue \\ met servikskanker', \\ Suid-Afrikaanse Tydskrif \\ vir Natuurwetenskap en \\ Tegnologie 34(1), Art. \\ \#1248, 5 pages. http:// \\ dx.doi.org/10.4102/satnt. \\ v34i1.1248

\section{Copyright:} \\ (C) 2015. The Authors. \\ Licensee: AOSIS \\ OpenJournals. This work is \\ licensed under the Creative \\ Commons Attribution \\ License.
}

Read online:
Servikskanker is een van die algemeenste kankertipes onder Suid-Afrikaanse vroue. In die afwesigheid van 'n voldoende voorkomende servikale sitologieprogram presenteer die meerderheid vroue met servikskanker in 'n gevorderde stadium. Die prognose van dié vroue, ondanks terapie, is beperk. Menslike immuniteitsgebreksvirus-infeksie (MIV-infeksie) benadeel die behandeling van servikale kanker. Servikskanker, en die behandeling daarvan, het'n impak op die lewenskwaliteit van die vroue. Die objektiewe bepaling van lewenskwaliteit kan lei tot aanpassing van behandeling, asook toepaslike ondersteuning. Hierdie studie is gedoen om die mees geskikte vraelyste vir Suid-Afrikaanse vroue met servikskanker te identifiseer. Die twee vraelyste wat internasionaal die meeste gebruik word, is die European Organisation for the Research and Treatment of Cancer (EORTC) en die Functional Assessment of Chronic Illness Therapy Measurement System (FACIT). Deur die sistematiese ondersoek van gepubliseerde artikels is die twee vraelyste aan die hand van spesifieke kenmerke geëvalueer. Hierdie kenmerke sluit in: studiestruktuur (dwarssnit of prospektief), lewenskwaliteituitkoms (primêr of sekondêr), tydstip van gebruik tydens die siekte en die nasionaliteit van die studiebevolking. Gebaseer op hierdie kenmerke is die EORTC as die mees geskikte vraelys geïdentifiseer.

The choice of an appropriate questionnaire for quality of life studies in South African women with cervical cancer. Cervical cancer is one of the commonest cancers among South African women. In the absence of an adequate, preventative cervical cytology programme, the majority of women present with an advanced stage of disease. Despite treatment, the prognosis for these women is poor. Furthermore, HIV and AIDS impacts adversely on the treatment of cervical cancer, whereas cervical cancer and its treatment again affect the quality of life. Objective assessment of the quality of life can improve treatment and supportive care. The current study was done to identify the most appropriate questionnaire to assess the quality of life experienced by South African women with cervical cancer. The European Organisation for the Research and Treatment of Cancer (EORTC) and the Functional Assessment of Chronic Illness Therapy Measurement System (FACIT) questionnaires are the most commonly used for assessment of the quality of life patients with cancer have. The current study assessed the appropriateness of these questionnaires for use in South Africa on the following criteria: study structure (prospective or transverse), quality of life endpoint (primary or secondary), timing of assessment during disease process and the nationalities of the study populations. The EORTC questionnaire was identified as the most appropriate for application to South African women with cervical cancer.

\section{Inleiding}

\section{Agtergrond tot servikskanker in Suid-Afrika}

Servikskanker verteenwoordig $18 \%$ van alle nuut gediagnoseerde kankergevalle onder Suid-Afrikaanse vroue. Die ouderdomspesifieke insidensie van servikskanker in Suid-Afrika is 26.8 per 100000 vroue (Arbyn et al. 2011). Hierdie statistiek is in teenstelling met die VSA, wat 'n ouderdomspesifieke insidensie van 5.7 per 100000 vroue het (Arbyn et al. 2011). Weens die feit dat vroue nie gereeld die nasionale servikale siftingstoets deur middel van servikale smere ondergaan nie, kom 'n verhoogde insidensie van dié tipe kanker voor onder Suid-Afrikaanse vroue (Denny 2012). Figuur 1 toon die Suid-Afrikaanse ouderdomspesifieke insidensie en mortaliteitskoers van servikskanker aan (World Health Organization [WHO] 2010). Hand aan hand met die gevorderde stadium gaan die hoë mortaliteitskoers van 14.8 per 100 000. Die vergelykende syfer in die VSA is 1.7 per 100000. 


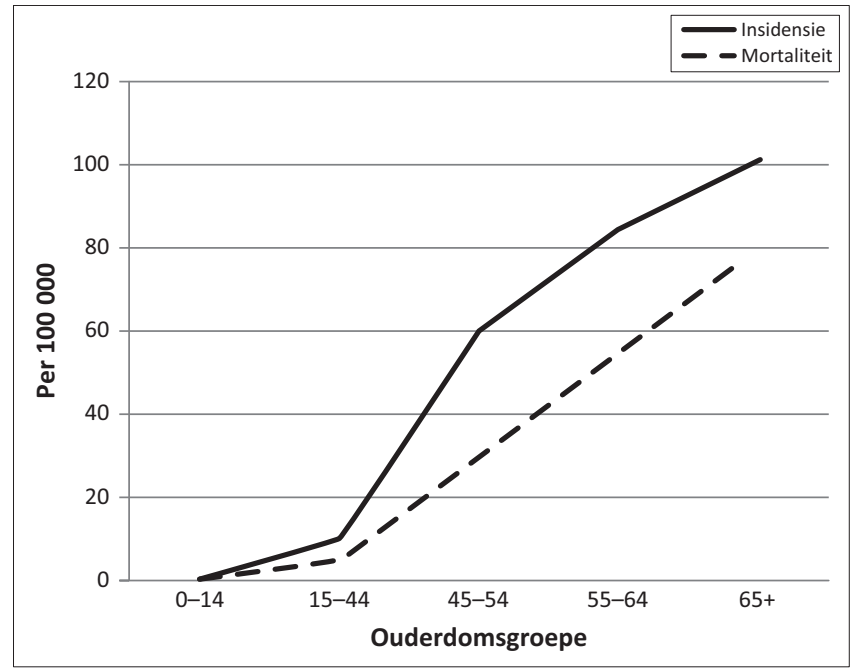

FIGUUR 1: Suid-Afrikaanse ouderdomspesifieke insidensie en mortaliteitskoers vir servikskanker.

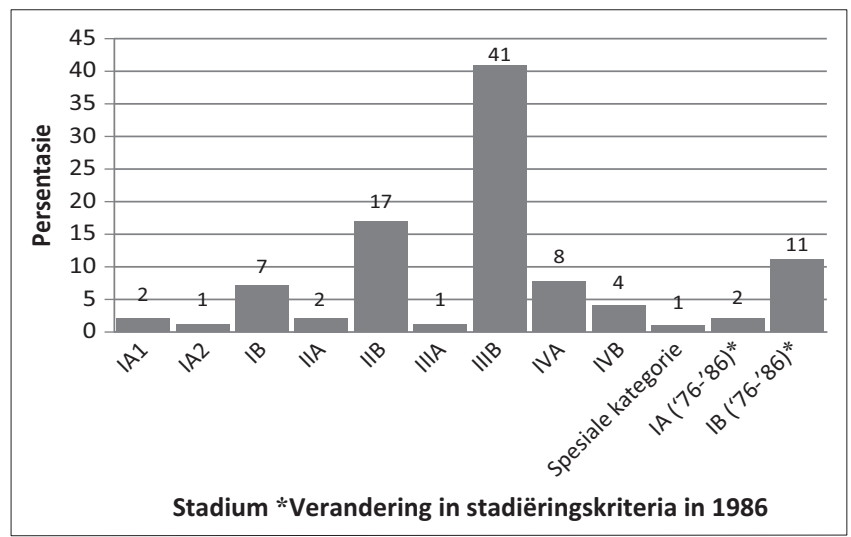

$n=3243$.

FIGUUR 2: Gevalle van servikskanker vir die tydperk 1976-1992 by Tygerberg Hospitaal.

Die rede vir verskille in die mortaliteitsyfer is die verspreiding van die verskil in stadium waarmee vroue in die onderskeie lande presenteer. Servikskanker word gestadieer volgens internasionale riglyne. Stadiums I en II word as vroeë stadiums beskou, aangesien hulle chirurgies behandel word. Stadiums III en IV is gevorderde stadiums en word deur bestraling behandel (National Cancer Institute). In ontwikkelde lande presenteer die meerderheid vroue met servikskanker in 'n vroeë stadium (Arbyn et al. 2011). 'n Studie wat by die Tygerberg Hospitaal gedoen is, het getoon dat $83 \%$ vroue met servikskanker in 'n gevorderde stadium gepresenteer het (Figuur 2). Die vyfjaaroorlewingsyfer in die algemeenste stadium van die siekte, naamlik stadium IIIB, is 35\% (Du Toit \& Smit 1997).

Verskille bestaan in die rasgekoppelde insidensie van die siekte. Die risiko vir 'n swart Suid-Afrikaanse vrou om servikskanker te ontwikkel, is 1 uit 34 (Denny 2012). Die ooreenstemmende syfer vir wit vroue is 1 uit 93 (Denny 2012). Hierdie verskille is die gevolg van ontoereikende primêre gesondheidsorg vir die laer sosio-ekonomiese swart en bruin groepe. Dié groepe het onvoldoende toegang tot voorkomende servikale sitologiedienste en dus presenteer hulle met gevorderde servikskanker (Denny 2012). Die gebruik van rasseklassifikasie in navorsing, en meer spesifiek in geneeskundige konteks, is kontroversieel. Van Niekerk (2011) stel dat rasseklassifikasie alleenlik in navorsing gebruik mag word indien dit bydra tot rasspesifieke toestande en hul gepaardgaande oplossings (Van Niekerk 2011). In die konteks van navorsing oor servikskanker is ras 'n merker van ontoeganklikheid tot primêre gesondheidsorgdienste en gevolglik presenteer servikskanker in 'n gevorderde stadium.

In die huidige studie oor vraelyste is die taal van sulke vraelyste ook relevant. Sekere Suid-Afrikaanse rasgroepe toon spesifieke taalvoorkeure. Die taalvoorkeure is gekoppel aan geografiese gebied. In die Wes-Kaap is isiXhosa, Afrikaans en Engels die voorkeurtale van die bevolking. Die taalvoorkeure in Gauteng is isiZulu, Engels en Afrikaans, en in die Vrystaat Sesotho, asook Afrikaans (South Africa.info). Die ervaring van lewenskwaliteit is 'n pasiënt se subjektiewe ervaring wat objektief deur middel van 'n vraelys bepaal word. Die vraelys moet in die pasiënt se moedertaal wees om voldoende uitdrukking te gee aan die betrokke individu se ervaring.

\section{Redes vir die bepaling van lewenskwaliteit}

Verskeie redes bestaan vir die bepaling van lewenskwaliteit by pasiënte met kanker. Die mees algemene rede is die evaluering van nuwe behandelingsmetodes. In dié konteks is die primêre uitkoms die effektiwiteit van die nuwe metode (Aaronson \& Sprangers 2011). Lewenskwaliteit is 'n sekondêre uitkoms in hierdie studies, maar het 'n belangrike rol in besluitneming indien die nuwe behandeling slegs geringe verbetering in oorlewing bied. In 'n situasie van palliatiewe sorg, waar oorlewing beperk is, is lewenskwaliteit die primêre uitkoms (Fayers \& Machin 2007). By die SuidAfrikaanse vrou met gevorderde servikskanker is die impak wat die toevoeging van chemoterapie tot radioterapie as behandeling op haar lewenskwaliteit het, van belang. Radioterapie was tot 1999 die internasionaal aanvaarde behandeling vir gevorderde servikskanker. Gebaseer op vyf publikasies oor die effektiwiteit van die kombinasie van radio- en chemoterapie (chemoradiasie-terapie), beveel die National Cancer Institute dit sedert 1999 as standaardterapie aan (National Cancer Institute). Chemoradiasie lei tot verhoogde toksisiteit met veral betekenisvolle beenmurgonderdrukking en dermkanaalskade. Data oor die impak van hierdie toksisiteit op lewenskwaliteit is nie beskikbaar nie (Green \& De 2004). Die oorlewingsvoordeel van vyf jaar wat chemoradiasie-terapie bied, teenoor slegs radioterapie, is $3 \%$ in stadium III-servikskanker (Green et al. 2005). 'n Verdere belangrike faktor ten opsigte van lewenskwaliteit onder Suid-Afrikaanse vroue met servikskanker is menslike immuniteitsgebreksvirus-infeksie (MIV-infeksie). Die SuidAfrikaanse bevolking het 'n 16\% insidensie van MIVinfeksie. MIV-insidensie onder vroue met servikskanker wissel tussen $7 \%$ - 21\% (Lomalisa, Smith \& Guidozzi 2000; Moodley 2006; Simonds et al. 2012). Servikskanker word deur die Amerikaanse Centers for Disease Control and Prevention geklassifiseer as definiërend vir verworwe 
immuniteitsgebreksindroom (VIGS) (Deeken et al. 2012). Die Wêreldgesondheidsorganisasie klassifiseer servikskanker as stadium IV-VIGS (Baveewo et al. 2011). Vroue met VIGS en servikskanker hanteer chemoterapie moeilik, aangesien lae CD4-tellings en gepaardgaande tuberkulose aanleiding gee tot vertraging en onvoltooide behandeling. Hierdie vertraagde en onvoltooide behandeling versleg prognose. In dié situasie word die toepaslikheid van chemoradiasie as behandeling bevraagteken en is lewenskwaliteit, asook die moontlike verlies daarvan weens chemoradiasie, belangrik (Simonds et al. 2012).

\section{Beskikbare vraelyste}

Fitzpatrick (1998) beskryf die vereistes waaraan vraelyste moet voldoen (Fitzpatrick et al. 1998). In onkologie is twee stelle vraelyste belangrik vir die bepaling van lewenskwaliteit. Die vraelyste is dié van die European Organisation for the Research and Treatment of Cancer (EORTC) en Functional Assessment of Chronic Illness Therapy Measurement System (FACIT) (Aaronson et al. 1993; Cella et al. 1993). Albei hierdie instellings het generiese vraelyste vir alle kankerpasiënte saamgestel. Bykomstig tot die generiese vraelys is daar ook orgaanspesifieke vraelyste. Die EORTC bestaan uit twee vraelyste, naamlik EORTC QLQ-C30 en QLQ-CX24. Die QLQ-C30 is 'n generiese vraelys wat in alle kankergevalle gebruik word. Die QLQ-CX24 is 'n vraelys wat spesifiek ontwerp is vir gevalle met servikskanker. Die ooreenstemmende FACIT-vraelyste is die Functional Assessment of Cancer Treatment-General (FACT-G) en die Functional Assessment of Cancer Treatment-Cervix (FACT-CX). Albei instellings se vraelyste voldoen aan internasionaal aanvaarde kriteria (Fitzpatrick et al. 1998).

\section{Doel van die studie}

Die huidige studie is gedoen om te bepaal watter vraelys die mees geskikte vir gebruik onder Suid-Afrikaanse vroue met servikskanker is.

\section{Metodes}

'n Sistematiese ondersoek is gedoen na alle beskikbare artikels wat van EORTC QLQ-C30/QLQ-CX24 of FACT-G/ FACT-Cx gebruik maak vir pasiënte met servikskanker. Toepaslike artikels is geïdentifiseer deur middel van die Pubmed, EBSCOhost Research Database, asook Google Scholar-soekfunksies. Die sleutelwoorde was 'cervical cancer', 'cervical carcinoma and quality of life'. Verdere artikels is geïdentifiseer deur die bronnelyste van artikels na te gaan. Die soektog is beperk tot artikels ná 1993. Dit is die jaar waarin sowel EORTC as FACT-G geyk is. Met die Suid-Afrikaanse agtergrond as vertrekpunt, is uitsluitlik op spesifieke aspekte van die gepubliseerde studies gefokus. Hierdie aspekte is: studie-ontwerp (prospektief of dwarssnit), uitkoms van lewenskwaliteit (primêre of sekondêre uitkomspunt), fase waarin die vraelys tydens die siekteproses gebruik is (eenmalig of herhalend, met verloop van tyd) en die nasionaliteit van die studiebevolking.

\section{Resultate}

'n Totaal van 28 artikels het voldoen aan die kriteria (Tabel 1). EORTC en FACT is albei gebruik in studies met prospektiewe of dwarssnitontwerp. In die EORTC-studies was die lewenskwaliteit in alle studies die primêre uitkoms, terwyl daar in die FACT-G-studies 'n 50\%-verdeling tussen primêre en sekondêre uitkomste was. Albei vraelyste is gebruik in eenmalige, dwarssnit- of prospektiewe evaluering van die siekteverloop. Die nasionaliteite van albei vraelyste sluit 'n wye reeks lande, ontwikkeld asook ontwikkelend in.

\section{Bespreking}

Die huidige sistematiese oorsig beoordeel die EORTCen FACT-vraelyste as moontlik geskikte vraelyste om lewenskwaliteitstudies onder Suid-Afrikaanse vroue met servikskanker te doen. Albei vraelyste is wyd verspreid in die literatuur gebruik. Lewenskwaliteit is al die primêre uitkoms in EORTC-studies. Hierteenoor is lewenskwaliteit slegs in 50\% van gevalle as primêre uitkoms in FACTstudies van belang. 'n Studie deur Cella (Cella et al. 2010) beklemtoon die belang van lewenskwaliteit as primêre uitkomspunt. Hy beskryf lewenskwaliteit as sekondêre uitkomspunt in 'n prospektiewe studie waartydens vier verskillende chemoterapie-regimes gebruik word in gevalle van stadium-IVB, herhalende of persisterende gevalle van servikskanker. Die primêre doel van die studie was die oorlewing van die verskillende chemoterapie-regimes. Tydens interim-analise, vier jaar na die aanvang van die studie, is bevind dat daar geen oorlewingsverskille tussen die onderskeie behandelingsopsies is nie, en dus is die studie gestaak. Die staking van die studie bring mee dat slegs 434 pasiënte (72\% van die beplande totaal wat beskikbaar was vir oorlewingsanalise) ingesluit is. Lewenskwaliteit-analise was slegs moontlik by 363 pasiënte (60\% van die beplande totaal). Die eindresultaat is ' $\mathrm{n}$ afname van $85 \%$ na $55 \%$ statistiese betekenisvolheid in die lewenskwaliteit-analise (Cella et al. 2010). Gebaseer hierop, is dit duidelik dat lewenskwaliteit as sekondêre uitkoms in studies in gevaar gestel word deur behandelinggekoppelde voortydige staking. Die nasionaliteite van die studiebevolkings is 'n weerspieëling van die insidensie van servikskanker. In die ontwikkelende lande is daar 'n hoë insidensie van servikskanker met gepaardgaande hoë mortaliteitskoers weens die gevorderde stadium waarin siekte gediagnoseer word. Die meerderheid van studies wat die FACT-G sisteem gebruik het, is uit die VSA. Waar studies die FACT-G in ander lande soos in die Filippyne en China gebruik het, is bevind dat daar spesifieke aanpassings in die vraelyste gemaak moes word omdat hulle nie geskik was binne daardie kulture nie. In teenstelling met die FACT sisteem, is EORTC in sowel ontwikkelde en ontwikkelende lande gebruik. Dit is onder verskeie kultuurgroepe as geskik beoordeel, byvoorbeeld Thailand, Sri-Lanka en Korea. Hierdie ontwikkelende lande het 'n soortgelyke insidensie van servikskanker as Suid-Afrika. 'n Belangrike aspek wat aan kultuur gekoppel kan word, is die beskikbaarheid van EORTC- en FACT-vraelyste in die 
TABEL 1: Oorsig van studies gebruik in sistematiese oorsig.

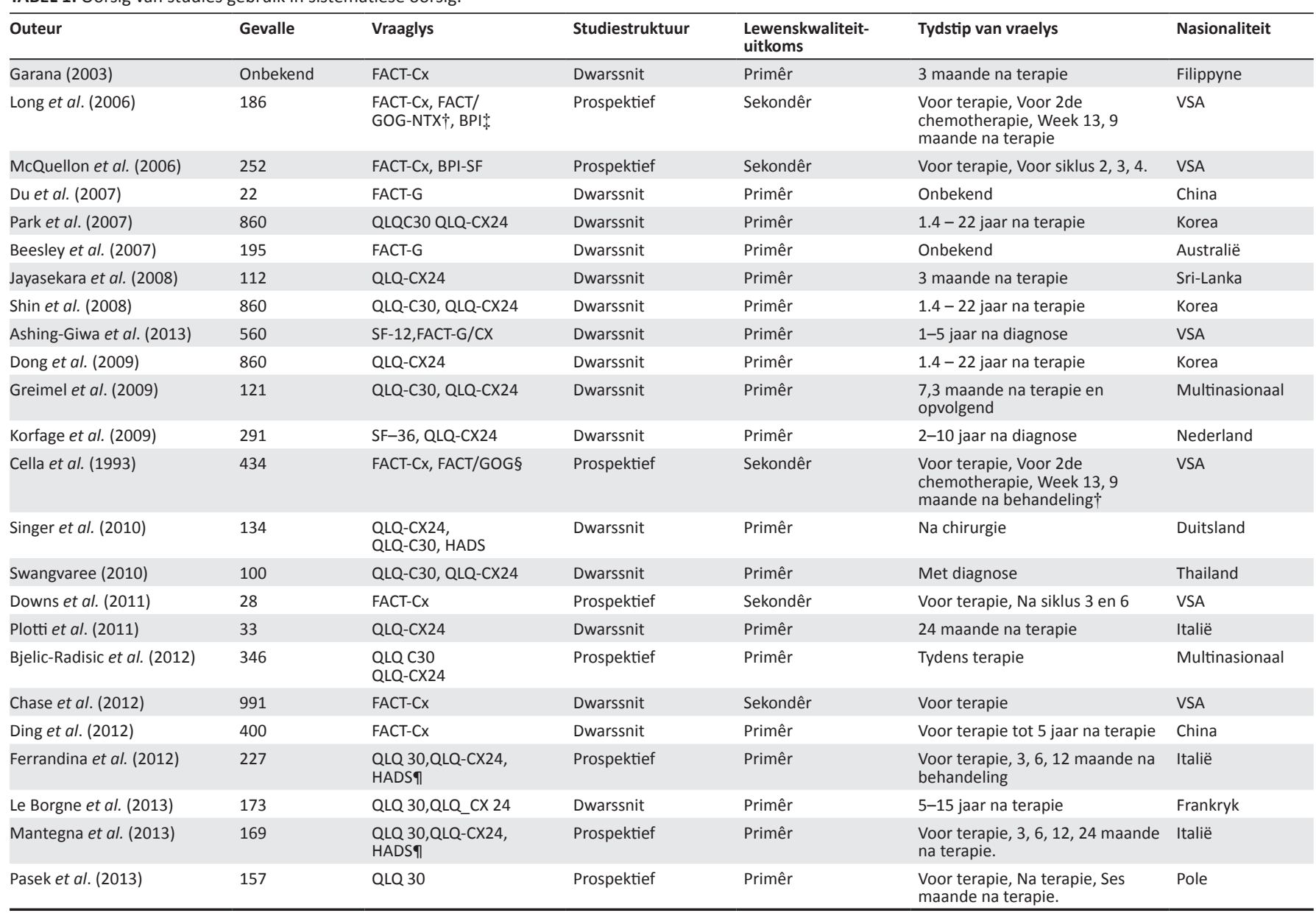

$\dagger$, Neurotoxicity Subscale (Subskaal van neurotoksisiteit).

$\$$, Brief Pain Inventory (Pynskaal).

$\S$, Gynecologic Oncology Group (FACT/GOG) four-item neurotoxicity scale (Ginekologiese onkologiegroep[FACT/GOG] vieritem-neurotoksisiteitskaal.

ๆ, Hospital Anxiety and Depression Scale (Angs- en depressieskaal in hospitaal).

Suid-Afrikaanse tale. Die EORTC C30/CX24 is in Afrikaans, isiXhosa en isiZulu beskikbaar, terwyl dit nie die geval is met FACT-G/Cx nie.

\section{Gevolgtrekking}

'n Geskikte vraelys vir studies oor lewenskwaliteit onder Suid-Afrikaanse vroue met servikskanker moet in die taal van hul keuse beskikbaar wees. Dit moet 'n geskiedenis hê van gebruik in studies waar lewenskwaliteit 'n primêre uitkoms is. Laastens moet dit gebruik kan word in 'n studiepopulasie met hoë insidensie van servikskanker en gepaardgaande gevorderde siektestadiums. Die EORTCvraelyste voldoen aan dié kriteria en geniet voorkeur as vraelys om die lewenskwaliteit van Suid-Afrikaanse vroue met servikskanker te bepaal.

\section{Erkenning \\ Mededingende belange}

Die outeur verklaar hiermee dat hy geen finansiële of persoonlike verbintenis het met enige party wat hom nadelig of voordelig kon beïnvloed het in die skryf van hierdie artikel nie.

\section{Literatuurverwysings}

Aaronson, N.K., Ahmedzai, S., Bergman, B., Bullinger, M., Cull, A., Duez, N.J. et al., 1993, 'The European Organization for Research and Treatment of Cancer QLQ-C30: A quality-of-life instrument for use in international clinical trials in oncology', Journal of the National Cancer Institute 85(5), 365-376. http://dx.doi. org/10.1093/jnci/85.5.365

Aaronson, N.K. \& Sprangers, M.A., 2011, 'Measuring quality of life in every oncological patient', Nederlands Tijdschrift voor Geneeskunde 155(45), A3749.

Arbyn, M., Castellsague, X., De Sanjose, S., Bruni, L., Saraiya, M., Bray, F. et al., 2011, 'Worldwide burden of cervical cancer in 2008', Annals of Oncology: Official Journal of the European Society for Medical Oncology / ESMO 22(12), 2675-2686.

Ashing-Giwa, K. \& Rosales, M., 2013, 'Evaluation of therapeutic care delay among Latina- and European-American cervical cancer survivors', Gynecologic Oncology 128(2), 160-165. http://dx.doi.org/10.1016/j.ygyno.2012.11.015

Baveewo, S., Ssali, F., Karamagi, C., Kalyango, J.N., Hahn, J.A., Ekoru, K. et al., 2011, 'Validation of World Health Organisation HIV/AIDS clinical staging in predicting initiation of antiretroviral therapy and clinical predictors of low CD4 cell count in Uganda', PLOS ONE 6(5), 1-7. http://dx.doi.org/10.1371/journal. pone.0019089

Beesley, V.L., Eakin, E.G., Janda, M. \& Battistutta, D., 2008, 'Gynecological cancer survivors' health behaviors and their associations with quality of life', Cancer survivors' health behaviors and their associations with quality of life', Cancer
Causes \& Control: CCC 19(7), 775-782. http://dx.doi.org/10.1007/s10552-008Causes
$9140-y$

Bjelic-Radisic, V., Jensen, P.T., Vlasic, K.K., Waldenstrom, A., Singer, S., Chie, W. et al. 2010 , 'Health-related quality of life outcomes associated with four cisplatin-based doublet chemotherapy regimens for stage IVB recurrent or persistent cervical cancer: A gynecologic oncology group study', Gynecologic Oncology 119(3), 531cancer: A gynecologic oncology group study', Gynecolo
537. http://dx.doi.org/10.1016/j.ygyno.2010.08.020

Cella, D.F., Tulsky, D.S., Gray, G., Sarafian, B., Linn, E., Bonomi, A. et al., 1993, 'The functional assessment of cancer therapy scale: Development and validation of the general measure', Journal of Clinical Oncology: Official Journal of the American Society of Clinical Oncology 11(3), 570-579. 
Chase, D.M., Huang, H.Q., Wenzel, L., Cella, D., McQuellon, R., Long, H.J. et al, 2012, 'Quality of life and survival in advanced cervical cancer: A Gynecologic Oncology Group study', Gynecologic Oncology 125(2), 315-319. http://dx.doi. Oncology Group study', Gynecologic
org/10.1016/j.ygyno.2012.01.047

Deeken, J.F., Tjen-A-Looi, A., Rudek, M.A., Okuliar, C., Young, M., Little, R.F. et al., 2012, 'The rising challenge of non-AIDS-defining cancers in HIV-infected patients', Clinical Infectious Diseases 55(9), 1228-1235. http://dx.doi.org/10.1093/cid/ cis613

Denny, L., 2012, 'Cytological screening for cervical cancer prevention', Best Practice \& Research Clinical Obstetrics \& Gynaecology 26(2), 189-196. http://dx.doi. org/10.1016/j.bpobgyn.2011.08.001

Ding, Y., Hu, Y. \& Hallberg, I.R., 2012, 'Psychometric properties of the Chinese version of the Functional Assessment of Cancer Therapy-Cervix (FACT-CX) measuring health-related quality of life', Health \& Quality of Life Outcomes 10(1), 124-133. http://dx.doi.org/10.1186/1477-7525-10-124

Dong, W.S., Ahn, E., Yong-Man, K., Kang, S., Byoung-Gie, K., Seong, S.J. et al., 2009 'Cross-cultural application of the Korean version of the European Organization for Research and Treatment of Cancer Quality of Life Questionnaire Cervical Cance Module', Oncology 76(3), 190-198. http://dx.doi.org/10.1159/000201571

Downs, L.S. Jnr., Chura, J.C., Argenta, P.A., Judson, P.L., Ghebre, R., Geller, M.A. et al., 2011, 'Ifosfamide, paclitaxel, and carboplatin, a novel triplet regimen for advanced, recurrent, or persistent carcinoma of the cervix: A phase II tria', Gynecologic Oncology 120(2), 265-269. http://dx.doi.org/10.1016/j.ygyno.2010.10.020

Du, A.Y., Zhang, J.W, Tang, L. \& Yu, M.J., 2007, 'Quality of life among gynecological patients after surgery' [in Chinese], Chinese Practical Journal of Gynecology and Obstetrics 23(3), 198-200.

Du Toit, G.C. \& Smit, B.J., 1997, 'Clinical prognostic parameters in Stage III cervical carcinoma', South African Medical Journal 87, 1434-1440.

Fayers, P. \& Machin, D., 2007, Quality of life: The assessment, analysis and interpretation of patient-reported outcomes, Wiley. http://dx.doi.org/10.1002/9780470024522

Ferrandina, G., Mantegna, G., Petrillo, M., Fuoco, G., Venditti, L., Terzano, S. et al., 2012, 'Quality of life and emotional distress in early stage and locally advanced cervical cancer patients: A prospective, longitudinal study', Gynecologic Oncology 124(3), 389-394. http://dx.doi.org/10.1016/j.ygyno.2011.09.041

Fitzpatrick, R., Davey, C., Buxton, M.J. \& Jones, D.R., 1998, 'Evaluating patient-based outcome measures for use in clinical trials', Health Technology Assessment (Winchester, England) 2(14), ia-iv, 1-74.

Garana, B., 2003, 'The functional assessment of cancer therapy scale for the Philippines: Reliability testing of the general measure and cervical cance subscale', Journal of Obstetrics \& Gynaecology Research 29(3), 195.

Green, J., Kirwan, J., Tierney, J., Vale, C.L., Symonds, P.R., Fresco, L.L. et al., 2005 'Concomitant chemotherapy and radiation therapy for cancer of the uterine cervix', Cochrane Database of Systematic Reviews 2005, 3. http://dx.doi. org/10.1002/14651858.CD002225.pub2

Green, J.A. \& De, B.L., 2004, 'Optimizing treatment for cervical cancer: The value of chemoradiation', American Journal of Cancer 3(4), 215-227. http://dx.doi. org/10.2165/00024669-200403040-00002

Greimel, E.R., Winter, R., Kapp, K.S. \& Haas, J., 2009, 'Quality of life and sexual functioning after cervical cancer treatment: a long-term follow-up study', Psychooncology 18(5), 476-482. http://dx.doi.org/10.1002/pon.1426

Jayasekara, H., Rajapaksa, L.C. \& Greimel, E.R., 2008, 'The EORTC QLQ-CX24 cervical cancer-specific quality of life questionnaire: psychometric properties in a South Asian sample of cervical cancer patients', Psycho-oncology 17(10), 1053-1057. http://dx.doi.org/10.1002/pon.1310

Korfage, I.J., Essink-Bot, M., Mols, F., Van de Poll-Franse, L., Kruitwagen, R. \& Van Ballegooijen, M., 2009, 'Health-related quality of life in cervical cancer survivors: A population-based survey', International Journal of Radiation Oncology, Biology, Physics 73(5), 1501-1509. http://dx.doi.org/10.1016/j. ijrobp.2008.06.1905
Le Borgne, G., Mercier, M., Woronoff, A., Guizard, A., Abeilard, E., CaravatiJouvenceaux, A et al.,2013, 'Quality of life in long-term cervical cancer survivors: A population-based study', Gynecologic Oncology 129(1), 222-228. http://dx.doi. A population-based study', Gynecolog
org/10.1016/j.ygyno.2012.12.033

Lomalisa, P., Smith, T. \& Guidozzi, F., 2000, 'Human immunodeficiency virus infection and invasive cervical cancer in South Africa', Gynecologic Oncology 77(3), 460463. http://dx.doi.org/10.1006/gyno.2000.5775

Long, H.J., Monk, B.J., Huang, H.Q., Grendys, E.C., McMeekin, D.S., Sorosky, J. et al., 2006, 'Clinical results and quality of life analysis for the MVAC combination (methotrexate, vinblastine, doxorubicin, and cisplatin) in carcinoma of the uterine cervix: A gynecologic oncology group study', Gynecologic Oncology 100(3), 537543. http://dx.doi.org/10.1016/j.ygyno.2005.09.023

Mantegna, G., Petrillo, M., Fuoco, G., Venditti, L., Terzano, S., Anchora, L.P. et al., 2013, 'Long-term prospective longitudinal evaluation of emotional distress and quality of life in cervical cancer patients who remained disease-free 2 years from diagnosis', BMC Cancer 13(1), 1-8. http://dx.doi.org/10.1186/1471-2407-13-127

McQuellon, R.P., Thaler, H.T., Cella, D. \& Moore, D.H., 2006, 'Quality of life (QOL) outcomes from a randomized trial of cisplatin versus cisplatin plus paclitaxel in advanced cervical cancer: A gynecologic oncology group study', Gynecologic Oncology 101(2), 296-304. http://dx.doi.org/10.1016/j.ygyno.2005.10.039

Moodley, M., 2006, 'Reduction in prevalence of invasive cervical cancer in KwaZuluNatal, South Africa: impact of the human immunodeficiency virus epidemic', International Journal of Gynecological Cancer: Official Journal of the International Gynecological Cancer Society 16(3), 1036-1040. http://dx.doi.org/10.1111/ j.1525-1438.2006.00588.x

National Cancer Institute, n.d., Cervical cancer treatment, viewed 07 January 2015, from http://www.cancer.gov/cancertopics/pdq/treatment/cervical/ HealthProfessional/page1/AllPages\#4

Park, S.Y., Bae, D.S., Nam, J.H., Park, C.T., Cho, C.H., Lee, J.M. et al., 2007, 'Quality of life and sexual problems in disease-free survivors of cervical cancer compared with the general population', Cancer 110(12), 2716-2725. http://dx.doi.org/10.1002/ cncr.23094

Pasek, M., Suchocka, L. \& Urbanski, K., 2013, 'Quality of life in cervical cancer patients treated with radiation therapy', Journal of Clinical Nursing 22(5), 690-697.

Plotti, F., Sansone, M., Di Donato, V., Antonelli, E., Altavilla, T., Angioli, R. et al., 2011 'Quality of life and sexual function after type C2/type III radical hysterectomy for locally advanced cervical cancer: A prospective study', The Journal of Sexual Medicine 8(3), 894-904. http://dx.doi.org/10.1111/j.1743-6109.2010.02133.x

Shin, D.W., Nam, J.H., Kwon, Y.C., Park, S.Y., Bae, D.S., Park, C.T. et al., 2008, 'Comorbidity in disease-free survivors of cervical cancer compared with the general femal population', Oncology 74(3-4), 207-215. http://dx.doi.org/10.1159/000151368

Simonds, H.M., Wright, J.D., Du Toit, N., Neugut, A.I. \& Jacobson, J.S., 2012, 'Completion of and early response to chemoradiation among human immunodeficiency virus (HIV)-positive and HIV-negative patients with locally advanced cervical carcinoma in South Africa', Cancer (0008543X) 118(11), 2971-2979.

Singer, S., Kuhnt, S., Momenghalibaf, A., Stuhr, C., Dimmel-Hennersdorf, U., Kohler U. et al., 2010, 'Patients' acceptance and psychometric properties of the EORTC QLQ-CX24 after surgery', Gynecologic Oncology 116(1), 82-87. http://dx.doi. org/10.1016/j.ygyno.2009.09.022

South Africa.info, n.d., The languages of South Africa, viewed 26 August 2014, from http://www.southafrica.info/about/people/language.htm\#.U_wnwPmSyGw

Swangvaree, S.K.T., 2010, 'The quality of life of cervical cancer patients', Journal of Public Health 8(1), 45-58.

Van Niekerk, A.A., 2011, 'Deliberating about race as a variable in biomedical research', South African Medical Journal 101(4), 248-250.

World Health Organization (WHO), 2010, WHO/ICO Information Centre on HPV and Cervical Cancer (HPV Information Centre), Human Papillomavirus and Related Cancers in South Africa, Summary Report 2010, viewed 07 January 2015, from http://www.who.int/hpvcentre 